\title{
COMPREENDENDO O SIGNIFICADO DE VIVENCIAR A DOENÇA MENTAL NA FAMÍLIA 1
}

Adriane M. Netto de Oliveira ${ }^{2}$

O estudo: "Compreendendo o Significado de Vivenciar a Doença Mental na Família - um Estudo Fenomenológico e Hermenêutico"', realizado com famílias que vivenciam a doença mental no seu cotidiano, buscou compreender o significado desta vivência para estes seres, à luz do referencial filosófico de Martin Heidegger. Na análise, emergiram quatro grandes temas: modos de ser da presença, percepção sobre o cuidado, ser cuidado e

A cura, pode ser proporcionada por um cuidado eficiente que favoreça ao ser humano ter um projeto de vida, assumindo o seu ser, tornando-se livre para reconhecer e escolher suas próprias possibilidades.

necessidades que emergem ao vivenciar a doença

mental. O modo de ser da família que vivencia a

doença mental, manifesta-se com autenticidade, emergindo sentimentos de angústia e sofrimento. Inicialmente, ocorre uma desorganização familiar e, posteriormente, a família consegue reorganizarse, priorizando o cuidado do seu familiar portador de doença mental. A equipe de saúde, na percepção da família, vivencia uma relação inautêntica com estes seres e com o seu familiar doente, mantendose, na maioria das vezes, indiferente a sua existência. Ser cuidado, para a família significa, prioritariamente, a preocupação com o seu ser, com os seus sentimentos e com o seu bem-estar. Ao vivenciar a doença mental, emerge a necessidade da família, de como deve agir com o seu familiar de modo a não prejudicá-lo, de informações relativas à doença, de apoio, de diálogo com os profissionais de saúde, da continuidade do tratamento, após a alta hospitalar e da busca das crenças religiosas como suporte.

Na maioria das vezes, a esperança de cura é ainda o sentimento que estimula a família a lutar contra a doença do seu familiar, por isso, faz-se necessário a esperança de cura como um instrumento de trabalho que ajuda a família a seguir em frente. Provavelmente, enquanto a família mantiver a esperança como suporte para enfrentar a doença, muitos caminhos poderão ser percorridos em busca da saúde mental de todos na relação familiar.

Inicialmente, a família busca a cura da doença, posteriormente, percebe que talvez esta possibilidade não possa concretizar-se, mas continua querendo a melhor qualidade de vida possível, para o seu familiar, constituindo-se aí, o significado da cura no pensamento heideggeriano. É preciso pensar a preocupação, a ocupação e a dedicação como cura, o que significa que esta pode encontrar-se em todo comportamento e situação da vida humana. A cura, pode ser proporcionada por um cuidado eficiente que favoreça ao ser humano ter um projeto de vida, assumindo o seu ser, tornando-se livre para reconhecer e escolher suas próprias possibilidades.

Outro aspecto relevante para a família do ser portador de doença mental é o reconhecimento da sua falta de coragem em questionar o "saber" do profissional médico, mesmo quando não consegue entender muitas de suas atitudes em relação ao cuidado e quando não compreende a doença. $O$ silêncio, como modo de discurso da família, possivelmente, seja um alerta de que esta tem muito a dizer, cabendo ao profissional de saúde reconhecer, nesse silêncio, o conteúdo do que ela tem a dizer. Na maioria das vezes, principalmente numa fase inicial da doença, a família não consegue ampliar sua visão sobre a doença mental, porque o conhecimento sobre ela não é partilhado, nem tampouco

${ }_{1}$ Resumo de Dissertação de Mestrado, defendida no Programa de Pós-Graduação Em Enfermagem - UFSC, em 2000.

2 Professora da Disciplina de Enfermagem Psiquiátrica, do Departamento de Enfermagem, da Fundação Universidade Federal do Rio Grande / FURG - Mestre em Assistência de Enfermagem. 
transmitido pelos profissionais de saúde. Por isso, é imprescindível que se estabeleça uma relação dialógica e de confiança com a família, para que possamos compreendê-la e ajudá-la a superar esta facticidade em sua vida.

A família percebe como importante a ajuda dos profissionais, especialmente, quando não consegue oferecer o auxílio que o seu familiar doente precisa. Pode ser difícil para a família assumir sozinha o cuidado do familiar doente, pela própria complexidade e instabilidade da doença mental. Possivelmente, durante algum tempo nesta trajetória, há a necessidade da ajuda do profissional de saúde, Ihe oferecendo um suporte, na medida em que vão surgindo dúvidas relativas à convivência cotidiana.

Oferecer a ajuda que a família necessita ao vivenciar a doença mental implica numa disponibilidade dos profissionais de saúde em considerar como relevante a presença destes seres para a recuperação do ser doente, ao mesmo tempo que requer, também, um preparo adequado e reciclagem constante daqueles que cuidam para que possam aprender a cuidar de quem cuida. 